\title{
Introduction: Exploring the Social and Educational Experiences of Black Canadian Youth over Time
}

While people of African descent have been living in Canada for centuries, their numbers became substantial only after changes in Canadian immigration laws culminated in the removal of the last explicitly racist and discriminatory provisions in 1967. Thousands of Black people arrived in Canada from the Caribbean starting in the 1970s, and smaller numbers came from Africa in subsequent years. The immigration of the late twentieth century not only increased the size of Canada's Black population but also changed its composition, with people of Caribbean heritage representing the largest group. The most common destination for these immigrants was Toronto.

The social and educational experiences of Black youth in Toronto have been a concern I have explored in much of my professional work since the 1980s, first as a youth worker in one of Toronto's most marginalized communities and subsequently as a professor, researcher, and equity advocate at York University. In the early days, the youth I worked with were almost all born in the Caribbean. Today, many Black youth are likely to be the children or grandchildren of Caribbean immigrants. Enough time has passed in the evolution of Toronto's Black community, as well as in the evolution of my own work, that we can look back and take stock.

A common understanding of immigration to Canada is that while the immigrant generation may struggle, things will be better for their children, and by the third generation substantial signs of social mobility and success in Canadian society will have begun to be evident. What emerges clearly from the studies referenced in this book is that this understanding has in large measure not held true for Black people in Canada. The reason it has not held true is the persistence of anti-Black racism, which Black youth experience in relation to gender, class, sexual identification, generational status, and area of residence, among other 
factors. Political, economic, cultural, social, and educational forces sustain racism as part of the inequitable structure of society. As a result, writings about Black youth years ago continue to be relevant today, and cumulative accounts of their experiences over generations make for helpful understanding of their lives.

\section{Theoretical Guides}

\section{Neoliberalism and Multiculturalism}

A prevailing framework for understanding individuals' lived experiences and life prospects is neoliberalism. We have a generally accepted notion that individuals can attain the education they desire, make choices, freely pursue employment opportunities, become wealthy, and take responsibility for their lives as they see fit. The neoliberal ethos, which informs these "common-sense" notions, also holds that competition constitutes an important "social good" and the "least restrictive way" of addressing and redistributing inequitable resources (Braedley \& Luxton, 2010, p. 8). Neoliberalism represents "a transnational political project" (Wacquant, 2008), based on the principles of a market economy in which individuals are free to pursue wealth without the constraints a welfare state might impose (Braedley \& Luxton, 2010; Wacquant, 2008). In this context, individuals and families must take responsibility for their own care and social outcomes (Braedley \& Luxton, 2010, p. 15).

Because the hegemonic neoliberal ideology of individualism and competition places responsibility for the circumstances of one's life on the individual, individuals tend to attribute their social or economic circumstances to having made poor choices rather than to the limited, problematic, or "bad" choices available to them. According to Luxton (2010), liberalism's "perverse form of individualism - an obstinate and persistent belief that blames the victim by privatizing social problems" - immobilizes individuals as they become resigned to the inevitability of their situation, failing to see that they have been formed by and subjected to the prevailing values and practices of the larger economic, social, and political structures (p. 172).

Despite neoliberalism's emphasis on individual choice, in a context of structural inequity, the resources and opportunities that individuals can access, and concomitantly their freedom and choices, are inevitably circumscribed by economic and social conditions over which they have little or no control (Braedley \& Luxton, 2010; Porfilio \& Malott, 2008; Tabb, 2003). The sustained attempts by neoliberal advocates "to promote competition, choice, entrepreneurship, and individualism" 
constitute what Connell (2010) calls a sociocultural logic (pp. 26, 27) that (theoretically) offers formerly excluded individuals access to opportunities without changing the existing "systems of inequality or the ideologies that sustain them" (p. 35).

In examining how youth are incorporated into "a global, neoliberal economic system," Sukarieh and Tannock (2008) argue that today's youth are caught in a capitalist system that has led to large populations of unemployed, working-class, poor, and racialized youth, typically residing in urban settings, with world views, identities, and ways of life that are oppositional or peripheral to the existing social order ( $\mathrm{p}$. 304). Educators and other youth service workers then set about to make them "fit functionally" into society, socializing them into a culture of responsibility and entrepreneurship, premised on white middle-class "standardized and universalized notions" of youth development. They learn that if they cannot "make it" in the existing employment market, it is because they "lack the skills of employability," and need to work harder on themselves "to better make it in the system" (p. 309). They also learn about the "ever-increasing educational requirements for jobs," which as Bills and Brown (2011) contend, amount to a practice of "credential inflation" (p. 2).

In Canada, the neoliberal ethos is both complemented and somewhat contradicted by the rhetoric of multiculturalism, which has been enshrined in both official policy (1971) and legislation (1988). The multicultural claim is that Canada promotes "inclusive citizenship" and guarantees the "value and dignity" of all citizens, "regardless of their racial and ethnic origins" and "their language or religious affiliation." From this perspective, Canada's promotion of cultural freedom, democracy, and equality enables "cultural groups" to preserve and maintain their culture. Canadian society is seen as "culturally neutral" and "colour-blind"; hence, race is believed not to have any effect on individuals' educational, social, and economic circumstances and opportunities.

However, recognition of "cultural groups" (i.e., minoritized groups) comes up against neoliberal insistence on individual responsibility and choice. And minoritized group members continue to experience educational, social, civic, and economic marginalization and exclusion (Basu, 2011, p. 1308; see also Reitz, Breton, Dion, \& Dion, 2009). Indeed, Canadian multiculturalism has been criticized for leading "to the hardening of ethnic and 'racial' stereotypes" (Satzewich \& Liodakis, 2010, p. 161), which also functions to position people targeted by those stereotypes at the margins of the society, preserving "the cultural hegemony of the dominant white cultural group" (Henry \& Tator, 2010, p. 39). And as Walcott and Abdillahi (2019) observe, in Canada's prevailing colonial 
paradigm, the dynamism of "the cultural arm of neoliberalism" is used to rationalize the inequitable situation in which Black youth exist, and the "moral regulation, guilt and self-blame" that constitute the ways in which they are racialized (p. 40).

\section{Critical Race Theory and Cultural Analysis}

To portray Canadian society in a way that is closer to the lived experience of its Black members, and Black youth in particular, a system of power relations in which race operates as a primary part of economic considerations - what Cedric Robinson (2000) refers to as "racial capitalism" - needs to be acknowledged. Rooted historically in European colonialization and the associated enslavement of African peoples, racism and discrimination towards Black people have been things that Black people have long resisted and against which they continue to struggle. In this regard, any analyses of Black people's experiences necessarily involve employing theoretical frameworks that centre race and draw attention to the agency that Black people have exercised in challenging the structural barriers and hurdles of inequity and racism in their bid to foster and maintain optimism and hope (Crenshaw, 2011; Gillborn, 2015; Howard, 2008; Ladson-Billings \& Tate, 1995; Nash, 2019).

Two such frameworks are critical race theory and cultural analysis. Critical race theory situates the experiences of people of colour at its centre and thus highlights how seemingly race-neutral and colour-blind practices and policies disproportionately affect minorities (Aylward, 1999, p. 34). According to Howard (2008), critical race theory holds that experiences and opportunities are significantly shaped by race and that "any attempt to eradicate racial inequalities has to be centred on the sociohistorical legacy of racism," which also means challenging the prevailing ideas of meritocracy, fairness, and objectivity that sustain societal discriminatory and exclusionary practices (p. 73; see also Charles, 2011; Gillborn, 2008; Stovall, 2008; Trevino, Harris, \& Wallace, 2011).

Critical race theory, as Zamudio, Russell, Rios, and Bridgeman (2011) write, "focuses on the all-encompassing web of race to further our understanding of inequality" (p. 3). It is "concerned with disrupting, exposing, challenging and changing racist policies that work to disenfranchise certain groups of people" and in the process "maintain the status quo" (Milner, 2008, p. 333). In today's context, that status quo is maintained through a pernicious new racism, which Balibar (2007) defines as

a racism whose dominant theme is not biological heredity but the insurmountability of cultural differences, a racism which, at first sight, does not 
postulate the superiority of certain groups or peoples in relation to others but "only" the harmfulness of abolishing frontiers, the incompatibility of life-styles and traditions. (p. 84)

All types of racism - from the individual to the institutional to the structural (or societal), which are all interlocking and reciprocal - make for a system of racism by which a process of racialization is maintained. This involves categorizing individuals into groups according to their physiological characteristics (specifically skin colour) and attributing abilities, cultural values, morals, and behaviour patterns to these characteristics (Henry \& Tator, 2010). Racialization serves to essentialize, homogenize, and generalize about the characteristics of minoritized group members, thereby ignoring group diversity and intragroup differences, and in the process, decontextualizing and dehistoricizing their experiences (Celious \& Oyserman, 2001). In relation to schooling and education, Howard (2008) writes that critical race theory

examines racial inequalities in educational achievement in a more probing manner than multicultural education, critical theory, or achievement gap theories by centering the discussion of inequality within the context of racism ... [Critical race theory] within education also serves as a framework to challenge and dismantle prevailing notions of fairness, meritocracy, colorblindness, and neutrality in the education of racial minorities. (p. 963)

Critical race theory as a framework serves to guide investigations, interpretations, and understandings pertaining to the saliency of race and concomitantly anti-Black racism evidenced in, among other concerns, deficit thinking about Black youth (and their families), and their treatment in schools, workplaces, neighbourhoods, and on the streets. In chronicling the voices, experiences, agencies, and ambitions of Black youth, this work provides critical insights into their world as they see it, and as they wish their world and their lives to be understood. Such understanding is critical to the construction of the needed counternarratives that must be told about why and how Black youth remain marginalized and disenfranchised members of Canadian society.

An important aspect of any critical scholarship in education is its use of "history as both a starting point and roadmap to navigate the contested terrain of race and White racism over time and geographic space" (Donnor, 2019, p. 20). To address the material condition of Black youth is, as Donnor (2019) points out, "not simply to articulate the continuity of White racism in education through voice, counter-storytelling and 
counter-narrative," but to reveal the nuances of the Negrophobia held by whites. Negrophobia, Donnor writes, is "the politically motivated and culturally informed sense of fear held by a majority of White people that their overall well-being will cease to exist" if Black people are "accorded a semblance of social, political, legal and material equality" (p. 16).

Cultural analysis gives attention to the structures and traditions that we all help to create, which in turn help to produce the circumstances in which individuals find themselves. McDermott and Varenne (2006) make the point that to fully understand and address the issues being investigated, we need to consider the cultural processes that underlie human interactions rather than merely focus on the individual. The idea, then, is to conceive of individuals' problems not simply as a product of their own making but as a product of the cultural worlds they occupy. As McDermott and Varenne assert,

Cultural analysis, like school reform, requires that we take persons seriously while analytically looking through them - as much as possible in their own terms - to the world with which they are struggling. It is not easy, but it is the best way to see them in their full complexity; anything less delivers a thin portrait of their engagements and leaves them vulnerable to being labeled, classified, diagnosed, blamed, charged, and found lacking without any consideration of how they have been arranged, misheard, unappreciated, set up, and denied by others. (p. 7)

Taking individual complexity into account requires moving beyond the individual, the school, and the dichotomies (such as success/failure, male/female, white/Black) into which we tend to place individuals; we need also to consider the culture of society, which shapes and is shaped by individuals. Indeed, as McDermott and Varenne (2006) proffer, "We have no choice but to study that which we also make" (p. 23). Categories such as race and gender are more than simple terms we use to identify and differentiate individuals - they mediate students' experiences and educational outcomes. In some cultural contexts, gender and race are used "to notice, regulate, and even distort individuals' points of order," making situations "dangerous enough to require constant vigilance" (p. 20).

Both cultural analysis and critical race theory foster a discussion about the intersection of race, gender, and class as they are lived, performed, experienced, and resisted in stratified societies where the culture is shaped, reshaped, and maintained through mechanisms such as racism, sexism, classism, heterosexism, and stereotyping. In Canada, the national multiculturalism discourse sustains the myth of a 
colour-blind, racially neutral society where culture is not informed by race (Henry \& Tator, 2010). However, we cannot ignore the integral role that race, and concomitantly racism, play in Canadian life.

In the case of Black youth, things such as low educational performance, over-representation in foster care and child welfare services, discriminatory police practices (such as carding), and high incarceration rates call for conscientious and consistent advocacy in the face of anti-Black racism (A. Benjamin, 2003; Lewis, 1992; Tecle, 2016; Walcott, 2017; Walcott \& Abdillahi, 2019). This naming points to the specificity of Black people's experiences with racism and is cognizant of the historicized and contextual constructs of race and its intersections with gender, class, sexuality, ability, citizenship, and other identity markers (Crichlow, 2016; McCready, 2010; Walcott, 2017; Walcott \& Abdillahi, 2019).

The clash between neoliberal and multicultural discourse on the one hand and the realities of Black life on the other can be seen in the strategies employed by some Black youth to navigate and resist the "web of stereotypes" (Howard, 2008, p. 966), which place them at a considerable disadvantage in the school system, work settings, and society generally. These youth work "twice as hard" to "prove" that they are intellectually "just as good" or even "better than" their white peers. Others work hard to prove that they are just as law-abiding and creditable citizens. This "extra work" - which Rockquemore and Laszloffy (2008) refer to as "race tax," and Ulysse (2015) calls "Black tax" - is considered part of the cost of being Black in a society where white supremacy mediates individuals' daily journeys through life. But in as much as the "extra work" might have helped some youth to attain their academic, athletic, and career ambitions, ironically, their successful achievements often tend to be used as evidence that whether or not an individual succeeds is a function of their hard work, not of inequities in society (Rockquemore \& Laszloffy, 2008). In other words, individual successes are used to mask the inequities against which individuals struggle.

Still other youth actively resist and contest the institutional structures, policies, and practices in schools, law enforcement agencies, and social services that hold in place the stereotypes which serve to oppress and pathologize Black people. Through their actions these youth seek recognition that the social system is unfair, making it difficult for them to gain access to the opportunities to which they are entitled like their white peers. The inevitable risk to these youth's resistive actions is that their "failures" or lack of "success" come to be used as justifiable "truths" about Black youth (James, 2019). And the possible fear that might be generated by their doing "extra work" and/or resisting the oppressive societal structures - because they seek not to confirm, but to 
act against, the stereotype - have led to not only intragroup differences among the youth but also inaction, thereby leaving the system and related inequities intact.

\section{Gendered Lives: The Particular Concerns for Black Boys and Young Men}

Throughout the years, starting with when I was a youth worker in downtown Toronto in the 1980s and since then as an educator and community-based researcher, students, parents, community members, youth workers, and educators have been drawing my attention to their concerns about the situation of Black male youth. These concerns have been consistent and today are seemingly more urgent. In an attempt to help address these concerns, in my research I have given particular, although far from exclusive, scrutiny to the situation of young Black men. This accounts for the number of chapters in this volume that take up issues and concerns pertaining to their social and educational situation, marginalization, and racialization. Indeed, the situation of Black female youth is not of any less interest or importance.

Clearly, it is necessary to give attention to how gender, race, and class create, perpetuate, and even determine social and educational pathways and outcomes of students, and to the related textured narratives, paradoxes, and complexities of their lived experiences. And notwithstanding the interlocking relationship of gender, race, ethnicity, class, sexual identity, and immigrant/citizenship status in a "White supremist, capitalist, patriarchal" society (hooks, 1992; see also Dua, 1999; Hill Collins, 2006), the ways in which gender operates to inform, structure, and configure Black youth's social and educational lives cannot be homogenized or generalized to the whole group. So, at times it becomes useful and necessary to centre the experiences of males or females to fully grasp, as Annette Henry (1993) writes, "the diverse historical, political, and economic forces within which Black lives are embroiled" (p. 214).

It is the intersection between race and gender that must be taken into account when theorizing Black masculinities. While Black males may be privileged by gender, that privilege is greatly mediated by the hegemonic structures of white masculinity which operates to subordinate and oppress them (McCready, 2010). On the basis of her study of Caribbean youth in New York City, López (2002) found that there were "differing race-gender outlooks [which] arise due to differences in experiences, perceptions and responses to racialization and gender(ing) processes, not biology" (p. 69). In Toronto as in New York City, young Black men have to contend with the general stereotypes of Black males 
as athletically rather than academically oriented, as low achievers, as troublemakers, and as behaviour-problem students. In "troubled" neighbourhoods, they face the additional stereotypes of Black young men as gang members, drug dealers, and gun users.

Both the statistical data from the Toronto District School Board 2011 Student Census analyzed in chapter 2 and the specific concerns examined in other chapters reveal the ways in which gender complicates the racialization of Black males. For example, the Student Census data revealed that 68 per cent of Black female high school graduates were confirmed in an Ontario postsecondary institution, compared to only 50 per cent of Black male graduates. More recent analysis of Toronto District School Board data indicate that one of the fastest growing and more successful group of students who are excelling in their academic work are Black females, while Black boys continue to be among the students with the lowest academic performance (Cameron, 2020).

Athletics figure prominently in several of the chapters, and are the main focus of chapter 6 . While both boys and girls participate in athletics, it is largely for boys that they come to occupy a central position during adolescence. For Black male youth, athletics are seen as a primary arena for the performance of Black masculinity. They are also held out as a fast track to a postsecondary education, especially in gaining entry to a university in the United States, and an escape route out of poverty. However, for the vast majority of young Black men these promises are illusory, and participation in athletics has the effect of diverting them from academic pursuits.

It should be noted that the ongoing concern with the educational and social conditions of young men has contributed, to some degree, to a dearth of scholarship on Black girls' experiences with schooling (George, 2020; A. Henry, 1993). In this regard, my attempt here is neither to overemphasize the conditions of males at the expense of females nor to have us generalize from the experiences of Black males. Rather, my goal is to use the research work in which I have engaged to provide extensive insights gained over a period of time about the lives of Black youth - much of which pertains to Black young men. And while anti-Black racism manifested towards and experienced by Black young women is similar, at some level and in some respects, to that experienced by young men, there are important differences that need to be accounted for. To this end, I invited colleagues with feminist scholarship and expertise to be part of this conversation through their responses.

In terms of athletics, for instance, in research I conducted on "the gendered experiences of female students in sports" (James, 2005, chap. 4) - in which I undertook a gendered analysis of Alicia, a 
twenty-four-year-old Black student athlete of Caribbean descent who went to university in the United States on an athletic scholarship - I concluded:

Given the structured gender inequity within society, and by extension within educational and athletic institutions, females do not have the same access and opportunities to educational and athletic opportunities as males. In reality, gender (in addition to the other demographic factors) helps to determine both the form and nature of females' participation and achievement in sports. Furthermore, sports, maintained as part of the male system of hegemony, will continue to be an arena in which females will be marginalized and undervalued. So, it is not merely a matter of individual females' choice, abilities, skills, or ambitions that determine their limits or possibilities, but the educational and athletic systems in which they participate, and the supports and encouragements they receive along the way. (p. 131)

The troubling schooling experiences of Black girls and young women and the costs to their educational and social trajectory - even as they outperform boys and young men in school - are addressed in the chapters about the social and historical schooling contexts of Black students (chapter 1), the significance of generational differences (chapter 2), the social and educational costs growing up in the suburbs (chapter 9), and what schooling is like for Black students in the early twenty-first century (chapter 10). The narrative that can be gleaned about Black girls and young women from these chapters is that they are subjected to anti-Black racism in which the interlocking relationship of Blackness and femaleness operates to inform how as students they are academically engaged, disciplined, and supported to graduation. As with their male peers, the academic abilities, schooling interests, and social ambitions of Black females are undervalued and underestimated by many of their white teachers (Annamma et al., 2019; Gaymes, 2006; George, 2020; Wood, 2011). All of this contributes to their inadequate school engagement, academic performance, and educational achievements, sustained by harsher disciplinary practices on the part of teachers. For instance, in their participatory action research which examined the schooling experiences of African-American females, Evans-Winters (2017) and her young researchers, Girls for Gender Equity, seeking an explanation for the punitive discipline to which their participants were subjected, found:

School officials viewed girls of color as a threat to the school environment itself. In particular, the girls reported that they were targeted for their style 
of dress, their hair, their attitude or character. In the words of the girls, they are viewed as "Dangerous Bodies." As non-White people, they are perceived as inherently violent; as nonwealthy youth, they are viewed as in need of discipline and control; and as girls of color, they are believed to be lacking morals and values. Thus, the body of a Black or Brown girl is seen as simultaneously an inherent threat to school officials and other students as well as a threat to her own safety and well-being. (p. 418)

Accordingly, just like their male peers, Black females are subjected to stereotypes that contribute to perceptions of them as disobedient, defiant, loud, having a bad attitude, and acting "ghetto" (Annamma et al., 2019; Gaymes, 2006; George, 2020; Linton \& McLean, 2017; Wood, 2011). And there is, as Kearie Daniel (2020) mentions - quoting Tanya Hayles, founder of Toronto-based Black Moms Connection - teachers' "adultification of our daughters."

\section{Studying Black Youth from Adolescence to Adulthood}

I have always wanted to know about the lives of participants I have studied beyond the single interaction I have had with them through one interview. To this end, I have often done longitudinal studies, in which I have interviewed participants at various points in their lives from adolescence though to adulthood. These studies provide insights into their life trajectories and the evolution of their thinking, often through their own words. Here, for example, is "Megan" (all of the names of participants here and elsewhere in the book are pseudonyms), whom I first interviewed in 1984 when she was in her third year at university:

You have to overcome [discrimination]. Not because it exists, I am going to lay down and die and don't bother trying. I know that it exists ... and I know what I have to do to overcome it. It calls for working hard. (Megan, age twenty-one, 1984)

I am as optimistic ... maybe now I am more realistic and I think it is possible [to make it] but with a big but [and that is] you have to take certain strategies to get there. It is not going to be easy ... but I can do it because I understand the hurdles and what you have to do to get over them. (Megan, age twenty-eight, 1991)

I wanted to make sure that I had everything that there was - nothing that the potential employer could look at to discount me. I heard the saying that Black people had to work twice as hard to get half as far. There was 
always that sense that you couldn't just be equal, you had to be better than. (Megan, age forty-three, 2006)

Like most of the other participants in the study, Megan referred to racism and discrimination as "hurdles" rather than "barriers." The participants preferred to think of them as mechanisms that might be overcome, sidestepped, or jumped over (to use an athletic metaphor) through their education, self-confidence, determination, and hard work. Megan's reflections tell of the impact of these "hurdles" in terms of attaining the career to which she aspired. Over the years, she remained determined, and as she said in 1991, "optimistic" but, with age, "a little more realistic." By 2006 she was married with children, living in a house in the suburbs, receiving a good salary, and holding a job in human resources in a large corporate firm in a downtown Toronto office tower. So, one would think Megan would have concluded that her strategy of determination and optimism had paid off and she had "made it," and hence that racism was not the "hurdle" she had feared. Nonetheless, Megan, like the seven others (two males and five females) who participated in the follow-up study I conducted in 2006, was resolute that race and racism were factors in their "struggles" to negotiate and attain their current jobs, and were realities about which they were constantly reminded and had to take into consideration as they journeyed through life (S. Benjamin, 2006).

The longitudinal study (1984-2006) in which Megan participated started with 60 youths between the ages of 17 and 22 years. ${ }^{1}$ Many of the participants ( 25 of the 60 or 42 per cent) aspired to professional and white-collar careers such as medicine, law, business, teaching, and social work, and were optimistic that even in the face of racism they would realize their career aspirations. And while race was generally perceived to be one "hurdle," gender, for females, was another. Thus

1 I interviewed 33 males and 27 females. At that time, they were high school students and graduates, school stop-outs and dropouts, college and university students, and full- and part-time employees. About 60 per cent of them were born in the Caribbean, 20 per cent in Toronto, 5 per cent in Halifax and fewer than 2 per cent in Britain to Caribbean parents. Among them, 15 per cent could be described as being of middle-class background (i.e., having parents in professional or white-collar jobs). They lived in the city's downtown area, the in-between suburbs, and the outer suburbs. I also conducted observations of youth gatherings at public and community events where I had informal conversations with Black youth and other attendees. These included youth programs, political demonstrations, student forums, Caribana activities, and Black Liberation Month events. 
Sharon, a participant in the 1984-5 study, stated, "Being a Black woman means that I have two strikes against me to start with, but that makes things challenging." So, for many of the youth, racism was taken to be a challenge by which they were invigorated or inspired to pursue their career goals - something they carried from their youth into their forties. The optimism of many of the participants seemed to be nurtured by their commitment to "represent" their community through their hard work. They worked, as Sharon also stated, "really, really hard" to be examples of what they were capable of doing and attaining.

Participants' optimism was supported by the self-confidence they had cultivated. They believed that they had what it took, and were doing what was necessary, to surmount the hurdles and struggles that they had come to accept as part of their everyday life. Larry, for example, who had just started work as a tool and die maker when he was interviewed in 1984, claimed that he was optimistic and confident that he would become "a foreman at [his] shop," and as he later added:

Another ten years I will have my own business even though there is discrimination, because I' $m$ a hard worker ... There is always going to be discrimination but there is always someone out there who is going to stand by your side. They don't necessarily have to be Black.

As adolescents, participants held confidently to the idea that they had ample qualities to achieve their aspirations: their education, hard work, skills, and tenacity. They also mentioned that they would "always have to be on guard, be extra careful and extra polite." These strategies, especially those relating to education, were meant, in the words of one participant, "to prove to white people that we can do something." In addition, they believed in their own agency, and the recognition they expected to receive from people who, as Larry said, would stand by them. However, by their late twenties, when I reconnected with 22 of the original 60 participants (then 24 to 29 years old) to conduct a follow-up study (1991), many had started to think that they could not achieve the opportunities and occupations they sought by themselves. They needed to work, as Sonia said in 1991, "in concert with other people of like minds because you can't take on the system by yourself even if you prove to be the brightest or best" (cited in James, 1993, p. 16). In my 1991 study, participants confessed their "naivety" and indicated that they were shifting their focus from exclusively individual efforts to addressing issues in the society. Nevertheless, they remained confident that their knowledge and understanding of the system as well as their 
education and abilities were sufficient to enable their success in a system they accepted as "not perfect."

I have followed the life journeys of many other Black youth over the years, and some of their stories are told in the chapters that follow. These stories help us discern to what extent the trajectories of subsequent generations of Black youth have differed from that of the 1980s generation and to what extent they have remained the same, as well as whether the harmful narrative of the underachieving, sports-minded, undisciplined, and troublesome Black youth, especially male Black youth, has persisted or changed over time.

\section{About the Essays}

This book brings together ten essays that I have written over a period of more than two decades. They cover various topics relating to the lives of Black youth (with a closer scrutiny of Black males) in the Greater Toronto Area, ranging from immigration to education to athletics to mentorship to encounters with the police. Several of the essays probe the lives of specific Black youth, in some cases tracing their journeys from high school through to adulthood, noting the ways in which, in the words of a research participant, "colour matters."

The essays have been edited for style, and in some cases shortened or expanded, but they have not been updated. Each essay reflects the time in which it was written. Taken together, as a collection written over time, the essays give rise to the question: What has changed in the lives of Black youth, and what has remained the same?

The book contains another element as well. Each essay is followed by a brief response from another scholar. These responses engage the topics I explore in the essays through different lenses: first of all, the lens of today rather than that of the time each essay was written. There are also different geographical lenses, as the respondents write from Britain, the United States, and other parts of Canada (Vancouver, St. Catharines, Ottawa, and Montreal) as well as Toronto. That most of the responses to the essays are by women scholars helps to deepen the discussion of the gendered lives of Black young people. Furthermore, each respondent brings their own scholarly interests, concerns, perspectives, and interpretations to understanding the differences, paradoxes, and contradictions of the lived experiences and circumstances of Black Canadian youth. In doing so, they provide insightful observations, thoughtful criticisms, alternative viewpoints, and provocative questions for us to consider. Their contributions alert us to what more might be said, or said differently, about the social, cultural, educational, political, and occupational worlds of Black youth. 
In addition to the responses to individual essays, Alissa Trotz's foreword and Michele Johnson's epilogue engage the collection as a whole, including the responses.

In this way, the book takes on the character of a conversation. My hope is that it will engender a wider conversation about the lives of Black youth, their prospects (or lack thereof) in Canadian society, and the structural barriers they face.

In chapter 1, "Historical and Social Context of the Schooling and Education of African Canadians," I outline the historical and social contexts of education from the 1970s to the first two decades of the twenty-first century, as well as the major policies, programs, and activities (and the events that led to them) initiated over the years in a bid to address Black students' schooling and educational issues. The chapter also documents the long-standing efforts of parents, educators, and community members to advocate effectively for Black students.

Chapter 2, "Generational Differences in Black Students' Education Pursuits and Performance," uses the Toronto District School Board (TDSB) 2011 Student Census data to examine the schooling and educational situation of Black students, focusing on intragroup generational and gender differences in terms of diversity. Findings indicate that third-generation students had lesser educational outcomes than their first-generation peers did, and that the differences between the various Black groups can be largely explained in terms of immigration patterns and experiences with inequity in the society. Continuing to explore the experiences of Black youth in relation to generational status, chapter 3, "'To Make a Better Future,'" presents the narrative of a 1.5-generation Caribbean-Canadian young man who immigrated to Canada in his early high school years and is now in his late thirties. The account is based on interviews with him conducted over an eighteen-year period, as well as his responses to the two versions of his story.

On the question of school disengagement, undisciplined behaviour, and educational underachievement of Black male students, chapter 4, "Students 'at Risk': Stereotypes and the Schooling of Black Boys," examines how stereotypes of Black male youth as immigrant, fatherless, troublemaker, athlete, and underachiever operate in the social construction of these youth as "at-risk" students. Continuing with the theme of education and Black males, in chapter 5, "More than Brains, Education, and Hard Work: The Aspirations and Career Trajectories of Two Young Black Men," I use case studies of two young African-Canadian men from the same stigmatized Toronto neighbourhood to critically discuss the commonly accepted claim that through education, intellectual ability, and hard work, individuals are able to attain the education and careers to which they aspire. While both of these young men 
are ambitious and well-schooled in the discourse of meritocracy, hard work, and dedication, one successfully attained his career goals while the other struggled to surmount the confounding obstacles of inequity.

Chapter 6, "Class, Race, and Schooling in the Performance of Black Male Athleticism," points to the ways in which race, class, and gender as marginalizing and racializing demographics - intersect in the construction of Black males as athletes, and in turn, the assumptions and expectations teachers and coaches have of them. Black males, as this essay discusses, are perceived to exist in a culture in which athletics define their Blackness, academic performance, career aspirations, and relationships with coaches and other role models. In chapter 7, "Troubling Role Models: Seeing Racialization in the Discourse Relating to 'Corrective Agents' for Black Males," the framework of new racism is used to interrogate the notion of mentorship and role models as "corrective agents" for Black youth, particularly males. Within the Canadian context of inequities, marginalization, and racialization in society, the need for strong mentors and role models for Black youth tends to be driven by the assumption that individual disposition or community cultural practices are responsible for the negative life circumstances experienced by Black youth.

Chapter 8, "'Up to No Good': Black on the Streets and Encountering Police," originally published in 1998, examines the nature of Black youth's encounters with police in public spaces and on the streets in particular. I argue that police and security personnel discretion and action (such as Stop, Search, and Question) are manifestations of patriarchal, colonial, and racist discourses employed to protect whiteness by symbolically containing the perception of the "dangerous Other." In chapter 9, "Colour Matters'": Suburban Life, Social Mobility and Its High Cost for Black Youth," I analyse the findings from research with youth and parents of Caribbean descent who are living in outer suburban areas of Toronto. While suburban neighbourhoods have come to represent desirable outcomes such as social mobility, safety, increased opportunity, and possibilities for success for those moving there, I note the "cost," in social, economic, cultural, and psychological terms, for Black youth of growing up in the suburbs.

By way of providing an update on the schooling and education of Black students, chapter 10, "Towards Equity in Education for Black Students," presents an abbreviated version of a report, Towards Race Equity in Education: The Schooling of Black Students in the Greater Toronto Area. Using Toronto District School Board data as reference, a team of us conducted investigative sessions in the Greater Toronto Area. The report documents what more than 300 parents, educators, community 
members, school administrators, and board trustees had to say about Black students' disengagement from school, poor academic performance, encounters with racial stereotyping, excessive surveillance, and educational underachievement, as well as about the streaming of Black students into nonacademic educational paths and how the racism of low expectations operated in their racialization and disenfranchisement.

This final chapter provides a context for understanding what one Black Toronto school administrator emailed to us about the fatal shooting of one of her Black male students two days after she participated in one of our sessions:

His death reminds me why it is so important to do something now. He was a bright young man who just needed a place to belong. We are losing too many of our young men to the streets and the violence that surrounds them. Hopefully creating an education system that does not negate or demonize Black bodies is a small but powerful request. (Personal communication)

Shortly after the report was released, the Toronto Star carried an editorial titled "Academic Streaming Harms Black Students" (2017). The editorial ended with an echo of this teacher's appeal: “This can't wait another twenty-five years. The school system should be a tool for redressing inequities, not compounding them."

\section{Finally ...}

The collection of essays tells about the experiences, optimism, ambitions, hopes, and challenges of generations of Black youth, many of them males, living in the Greater Toronto Area. The insights provided by the youth about their lives - told, captured, and reported largely in their own words - reveal the extent to which their educational and career aspirations have been realized, how their respective strategies effectively served them, and how much has changed or remained the same over the years. What is clear is the roles that enablers such as parents, peers, teachers, coaches, and others played over time in the life trajectory of Black youth as they negotiated and navigated the systems of racism and discrimination sustained by social and economic structures of inequity.

Until government and institutional leaders acknowledge anti-Black racism, and put in place structures - not just temporary programs - to address the situation of Black youth, then the optimism and hope that characterize this pivotal stage of life will likely wane. There needs to 
be widespread acceptance that in an interrelated world the situation of Black youth affects society generally. In other words, the social, economic, cultural, emotional, and health cost of Black youth and their communities is also borne by the entire society. If indeed we are to respond productively to the needs, experiences, and aspirations of Black youth and their parents and communities, then all of society must become acquainted with their lived realities and agency to create and reimagine the needed counternarrative that will lead to their "making it" in terms of achieving success and living healthy, meaningful lives. The novel coronavirus has exposed the dangerous cost of inequity. In fact, the pandemic, COVID-19, has not only highlighted the inequities and the inherent barriers to productive lives but also exacerbated the problems by adding another layer to the marginalization and racialization of Black youth. Therefore, there is an urgent need for changes in societal and institutional regulations, policies, programs and practices if Black youth are to gain the opportunities and privileges in society to which they are entitled.

\section{REFERENCES}

Academic streaming harms black students. [Editorial]. (2017, April 30). Toronto Star. https:/ /www.thestar.com/opinion/editorials/2017/04/30/academic -streaming-harms-black-students-editorial.html

Annamma, S.A., Anyon, Y., Joseph, N.M., Farrar, J., Greer, E., Downing, B., \& Simmons, J. (2019). Black girls and school discipline: The complexities of being overrepresented and understudied. Urban Education, 54(2), 211-42. https: / / doi.org/10.1177/0042085916646610

Aylward, C.A. (1999). Canadian critical race theory: Racism and the law. Halifax, NS: Fernwood.

Balibar, E. (2007). Is there a "neo-racism"? In T. Das Gupta, C.E. James, G-E. Galabuzi, \& C. Andersen (Eds.), Race and racialization: Essential readings (pp. 83-8). Toronto, ON: Canadian Scholars' Press.

Basu, R. (2011). Multiculturalism through multilingualism in schools: Emerging places of "integration" in Toronto. Annals of the Association of American Geographers, 101(6), 1307-30. https:/ / doi.org/10.1080/00045608 .2011 .579536

Benjamin, A. (2003). The Black/Jamaican criminal: The making of ideology (unpublished doctoral dissertation). Toronto: Ontario Institute of Studies in Education, University of Toronto.

Benjamin, S. (Director). (2006). Making it [Film]. Canada: National Film Board of Canada, CitizenShift. https: / / www.nfb.ca/film/making_it 
Bills, D.B., \& Brown, D.K. (2011). New directions in educational credentialism. Research in Social Stratification and Mobility, 29(1), 1-4. https:/ / doi.org /10.1016/j.rssm.2011.01.004

Braedley, S., \& Luxton, M. (2010). Competing philosophies: Neoliberalism and the challenges of everyday life. In S. Braedley \& M. Luxton (Eds.), Neoliberalism and everyday life (pp. 3-21). Montreal, QC: McGill-Queen's University Press.

Cameron, D.H. (2020). Black student experience in TDSB schools. Toronto, ON: Toronto District School Board, Research Department.

Celious, A., \& Oyserman, D. (2001). Race from the inside: An emerging heterogeneous race model. Journal of Social Issues, 57, 149-65. https: / / doi.org/10.1111/0022-4537.00206

Charles, H. (2011). Toward a critical race theory of education. Contemporary Justice Review, 11(1), 63-5. https:/ / doi.org/10.1080/10282580701850413

Connell, R. (2010). Understanding neoliberalism. In S. Braedley \& M. Luxton (Eds.), Neoliberalism and everyday life (pp. 22-36). Montreal, QC: McGillQueen's University Press.

Crenshaw, K.W. (2011). Twenty years of critical race theory: Looking back to move forward. Connecticut Law Review, 43(5), 1253-352. https: / / opencommons.uconn.edu/law_review /117

Crichlow, W. (2016). Human rights, intersectionality and Black LGBTQ institutional invisibility. Racial Profiling Policy Dialogue, Ontario Human Rights Commission. Toronto, ON: York University.

Daniel, K. (2020, April 22). Being a tiger mom is an act of love - and necessity. Flare. https: / www.flare.com/identity/tiger-parenting-style-black-tiger-mom/

Donnor, J.K. (2019). Understanding the why of whiteness: Negrophobia, segregation, and the legacy of white resistance to Black education in Mississippi. In J.T. DeCuir-Gunby, T.K. Chapman, \& P.A. Schutz (Eds.), Understanding critical race research methods and methodologies: Lessons from the field (pp. 13-23). New York, NY: Routledge.

Dua, E. (1999). Canadian anti-racist feminist thought: Scratching the surface of racism. In E. Dua \& A. Robertson (Eds.), Scratching the surface: Canadian antiracist feminist thought (pp. 7-31). Toronto, ON: Women's Press.

Evans-Winters, V.E. (with Girls for Gender Equity). (2017). Flipping the script: The dangerous bodies of girls of color. Cultural Studies, 17(5), 415-23. https: / / doi.org/10.1177/1532708616684867

Gaymes, A. (2006). Making spaces that matter: Reflections on the experiences of female students in a Toronto school (Unpublished master's thesis). Faculty of Education, York University, Toronto, ON.

George, R.C. (2020). Holding it down? The silencing of Black female students in the educational discourses of the Greater Toronto Area. Canadian Journal of Education, 43(1), 32-58. 
Gillborn, D. (2008). Racism and education: Coincidence or conspiracy. London, UK: Routledge.

Gillborn, D. (2015). Intersectionality, critical race theory and the primacy of racism: Race, class, gender and disability in education. Qualitative Inquiry, 21(3), 277-87. https:/ / doi.org/10.1177/1077800414557827

Henry, A. (1993). Missing: Black self-representation in Canadian educational research. Canadian Journal of Education, 18(3), 206-22. https: / / doi.org $/ 10.2307 / 1495383$

Henry, F., \& Tator, C. (2010). The colour of democracy: Racism in Canadian society (4th ed.). Toronto, ON: Nelson Education.

Hill Collins, P. (2006). A telling difference: Dominance, strength, and black masculinities. In A.D. Mutua (Ed.), Progressive Black masculinities (pp. 73-98). New York, NY: Routledge.

hooks, b. (1992). Black looks: Race and representations. Boston, MA: South End Press.

Howard, T.C. (2008). Who really cares? The disenfranchisement of African American males in preK-12 schools: A critical race theory perspective. Teachers College Record, 110(5), 954-85.

James, C.E. (1993). Getting there and staying there: Blacks' employment experience. In P. Axelrod \& P. Anisef (Eds.), Transition: Schooling and employment in Canadian society (pp. 3-20). Toronto, ON: Thompson Educational Publishing.

James, C.E. (2005). Race in play: Understanding the socio-cultural worlds of student athletes. Toronto, ON: Canadian Scholars' Press.

James, C.E. (2019). Adapting, disrupting and resisting: How middle school Black males position themselves in response to racialization in school. Canadian Journal of Sociology, 44(4), 373-97. https: / / doi.org/10.29173 /cjs29518

Ladson-Billings, G., \& Tate, W.F. (1995). Toward a critical race theory of education. Teachers College Record, 97(1), 47-68.

Lewis, S. (1992, June 9). Report on race relations in Ontario. Toronto, ON: Government of Ontario.

Linton, R., \& McLean, L. (2017). I'm not loud, I'm outspoken: Narratives of four Jamaican girls' identity and academic success. Girlhood Studies, 10(1), 71-88. https: / / doi.org/10.3167/ghs.2017.100106

López, N. (2002). Race-gender experiences and schooling: Second-generation Dominican, West Indian, and Haitian youth in New York City. Race Ethnicity and Education, 5(1), 67-89. https://doi.org/10.1080/13613320120117207

Luxton, M. (2010). Doing neoliberalism: Perverse individualism in personal life. In S. Braedley \& M. Luxton (Eds.), Neoliberalism and everyday life (pp. 163-83). Montreal, QC: McGill-Queen's University Press. 
McCready, L.T. (2010). Making space for diverse masculinities: Difference, intersectionality, and engagement in an urban high school. New York, NY: Peter Lang.

McDermott, R., \& Varenne, H. (2006). Reconstructing culture in educational research. In G. Spindler \& L. Hammonds (Eds.), Innovations in educational ethnography (pp. 3-31). Mahwah, NJ: Lawrence Erlbaum Associates.

Milner, H.R. (2008). Critical race theory and interest convergence as analytical tools in teacher education policies and practices. Journal of Teacher Education, 59(4), 332-46. https: / / doi.org/10.1177/0022487108321884

Nash, J.C. (2019). Black feminism imagined after intersectionality. Durham, NC: Duke University Press.

Porfilio, B., \& Malott, C. (Eds.), The destructive path of neoliberalism: An international examination of urban education. Rotterdam, Netherlands: Sense Publishers.

Reitz, J.G., Breton, R., Dion, K.K., \& Dion, K.L. (2009). Multiculturalism and social cohesion: Potentials and challenges of diversity. New York, NY: Springer.

Robinson, C.J. (2000). Black Marxism: The making of the Black radical tradition. Chapel Hill, NC: University of North Carolina Press.

Rockquemore, K., \& Laszloffy, T. (2008). The Black academic's guide to winning tenure without losing your soul. Boulder, CO: Lynne Rienner.

Satzewich, V., \& Liodakis, N. (2010). "Race" and ethnicity in Canada: A critical introduction. Toronto, ON: Oxford University Press.

Stovall, D. (2008). Forging community in race and class: Critical race theory and the quest for social justice in education. Race Ethnicity and Education, 9(3), 243-59. https:/ / doi.org/10.1080/13613320600807550

Sukarieh, M., \& Tannock, S. (2008). In the best interests of youth or neoliberalism? The World Bank and the new global youth empowerment project. Journal of Youth Studies, 11(3), 301-12. https: / / doi.org/10.1080 /13676260801946431

Tabb, W.K. (2003). Du Bois vs. neoliberalism. Monthly Review, 55(6), 33-40. https: / / doi.org/10.14452/MR-055-06-2003-10_4

Tecle, S. (2016, Winter). Anti-Blackness: Official myths aside, Canadian anti-Black racism is alive and deadly. Canadian Dimension, 50(1). https:/ / canadiandimension.com/articles/view/anti-blackness

Trevino, A.J., Harris, M.A., \& Wallace, D. (2011). What's so critical about critical race theory? Contemporary Justice Review, 11(1), 7-10. https: / / doi.org/10.1080/10282580701850330

Ulysse, G.A. (2015, December 7). Pedagogies of belonging. Huffington Post. http:/ / www.huffingtonpost.com/gina-athena-ulysse/pedagogies-of -belonging_1_b_8693286.html

Wacquant, L. (2008). Urban outcasts: A comparative sociology of advanced marginality. Cambridge, UK: Polity Press. 
Walcott, R. (2017). Queer returns: Essays on multiculturalism, diaspora, and Black studies. Toronto, ON: Insomniac Press.

Walcott, R., \& Abdillahi, I. (2019), Blacklife: Post-BLM and the struggle for freedom. Winnipeg, MB: ARP Books.

Wood, M. (2011). Banking on Education: Black Canadian females and schooling (unpublished doctoral dissertation). Faculty of Education, York University, Toronto, ON.

Zamudio, M.M., Russell, C., Rios, F.A., \& Bridgeman, J.L. (2011). Critical race theory matters: Education and ideology. New York, NY: Routledge. 